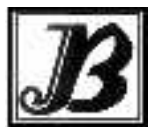

J. bio-sci. 21: 43-49, 2013

ISSN 1023-8654

http://www.banglajol.info/index.php/JBS/index

\title{
A COMPARATIVE STUDY OF USING FORMALIN IN FISH OF TANGAIL AND TONGI TOWN
}

\author{
Luthfunnesa Bari1 ${ }^{*}$, M. Ariful Islam¹, Zannatul Ferdous ${ }^{1}$, M. Atiqul Azman¹, Shahanaz Khatun², \\ Md. Imam Hossain ${ }^{3}$
}

${ }^{1}$ Department of Food Technology and Nutritional Science, Mawlana Bhashani Science and Technology University, Santosh, Tangail. '2Department of Biochemistry and Molecular Biology, University of Rajshahi, Rajshahi, Bangladesh. ${ }^{3}$ Department of Biotechnology \& Genetic Engineering, Mawlana Bhashani Science and Technology University, Santosh, Tangail, Bangladesh

\begin{abstract}
Context: Recent reports of media have brought great attention to the problem of formalin used by whole sellers and venders in preserving fish. It is evident from several studies that fish items in different markets in Bangladesh are treated with formalin for preservation which is highly hazardous and carcinogenic chemical.

Objectives: The study was undertaken to determine the presence of formalin in fishes collected from various wet markets of Tangail and Tongi town.

Materials and Methods: From 12 selected wet markets, various species of fishes were collected and presence of formalin was detected using the "formalin detection kit in fish" developed by Bangladesh Council of Scientific and Industrial Research (BCSIR).

Results: It was found that 16 fishes were formalin contaminated out of 192 fish samples in which $0 \%$ in Santosh bazar, $11.11 \%$ in Soi ani bazar, $13.33 \%$ in Park bazar, $14.81 \%$ in Old bus stand bazar, $0 \%$ in Chara bari bazar and $12.82 \%$ in New bus stand bazar of Tangail town. On the other hand, 33 formalin contaminated fish out of 171 were obtained in which $0 \%$ in Coto bazar, $20 \%$ in Gazipura bus stand bazar, 37.5\% in Chourasta bazar, $0 \%$ in Boro bari bazar, 36.36\% in CheragAli bazar and 20\% in Tongi bazar of Tongi town. The study indicates that almost $8.33 \%$ of fish samples in Tangail town and $19.29 \%$ of fish samples in Tongi town were formalin contaminated.

Conclusion: The present study revealed that in Tangail town $75 \%$ imported fish and $25 \%$ local fishes were formalin contaminated whereas in Tongi town, $82 \%$ imported fishes and $18 \%$ local fishes were formalin contaminated.
\end{abstract}

Key words: Formalin; BCSIR, Formalin detection kit; Shelf-life.

\section{Introduction}

Bangladesh is a country with hundreds of rivers and ponds and is notable for being a fish-loving nation. Fishes are an important part of a healthy diet and are considered as the biggest source of protein (Ashie et.al.1996). About $90 \%$ of animal protein in our diet comes from fish and live stock (MoFL 2011). Fish and fishery products are the country's third largest export commodity contributing $5.10 \%$ of its exchange earnings in 2002-2003 Bangladesh earned US\$ 324 million of which shrimp alone contributed $72 \%$ of the total by quantity and $89 \%$ by value (FAO, 2011). Although the total fish production has increased significantly over the last few decades (DoF 2009), but it is still not sufficient proper preservation system in our country. Actually fishes are perishable in nature. In order to keep the freshness of fish, traders tend to intentionally and carelessly use formaldehyde as preservative agent. Formalin is a generic term which describes a solution of $37 \%$ formaldehyde gas dissolved in water (Noordiana et al. 2011). Foods dipped in formalin are harmful to health and people after using them over a prolonged period can develop respiratory and neurological problems along with cancer, liver cirrhosis, kidney, lung, allergy, asthma and other health

•Corresponding address E-mail: mslbari@hotmail.com 
hazards warn health experts. The changes in the kidneys and liver consist of cloudy swelling, fatty degeneration, focal necrosis and leucocytic infiltration. The injection of formalin into the lungs is followed by pneumonia and bronchitis. High doses due to continuous use of it may lead to death (Martin 2010). Nowadays the dishonest businessmen are using formalin in fish, fruit, milk and others perishables including vegetables to keep freshness or shelf life for longer time (Sapthahic-2000, 2011). They have very little knowledge about formalin's effect on human body. They know very well that formalin is not allowed to use in fish in our or in foreign countries.

There is no information available about the using of formalin in fishes at various wet market in these region. The objective of this study was to survey the rate of formalin using in fish and compare this rate between Tangail and Tongi town, Bangladesh.

\section{Materials and Methods}

\section{Fish sample collection}

A total of 363 fish samples were collected. Six wet markets in Tangail town and six markets in Tongi town were selected according to their location, large scale marketing and economic condition of the inhabitants etc. The markets in Tangail town include Santosh bazar, Soi ani bazar, Park bazar, Godaon bazar (old bus stand), Chara Bari bazar and New bus stand bazar. The markets of Tongi town were Coto bazar, Gazipura bus stand bazar, Chourasta bazar, Boro bari bazar, Cherag ali bazar and Tongi bazar. Various fish sample e.g. Mrigel (Cirrhinus cirrhosus), rui (Labeo rohita), kal baoush (Labeo calbasu), catla (Catla catla), silver karp (Hypophthalmichthys molitrix), boal (Wallago attu), elish (Tenualosa ilisha), telapia (Oreochromis mossambicus), aaeer (Sperata aor), baeem (Mastacembelus armatus), chitol (Chitala chitala), foli (Notopterus notopterus), koi (Anabas testudineus), sorputi (Puntius sarana), etc were collected from selected wet markets.

\section{Qualitative detection of formalin using formalin detection kit for fish}

Qualitative detection of formalin was performed by the formalin detection kit for fish developed by Bangladesh Council of Scientific and Industrial Research (BCSIR). This kit contains three different solutions labeled as solution 1, 2 and 3 . First, the samples were washed with small quantity of water and a portion of washed out water was taken in a test-tube using a dropper incorporated in the kit. 15 drops of solution 1 was added in the test-tube containing washed out water. After well stirring, the solution was allowed react for 30 seconds. 15 drops of solution 2 was added in the same test-tube. After waiting for 30 seconds, solution 3 was added, change in color pink or red indicated the presence of formalin whereas unchanged color indicated the sample is free from formalin (Fig.1).

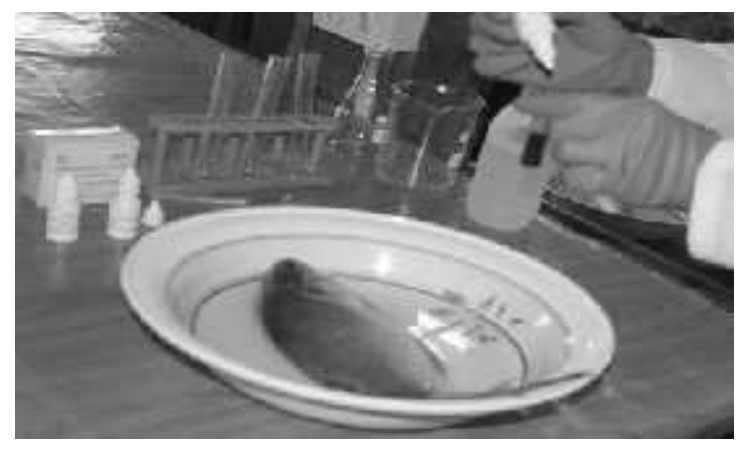

Fig. 1. Formalin detection in fish with formalin detection kit developed by BCSIR. 


\section{Result and Discussion}

Studies were conducted on the detection of formalin in fish obtained from different wet markets in Tangail and Tongi town and the results are presented in Table 1 and Table 2 respectively.

Table 1. Formalin detection in fish in Tangail town.

\begin{tabular}{|c|c|c|c|c|c|}
\hline Name of the bazar & Name of the fish & Source & No. of fish & Formalin presence & Percentage (\%) \\
\hline \multirow[t]{9}{*}{ Santosh bazar } & Mrigel & Beel & 03 & Nil & \multirow{9}{*}{$0 \%$} \\
\hline & Karfu & Pond & 03 & Nil & \\
\hline & Rui & River & 03 & Nil & \\
\hline & Bighead & Pond & 03 & Nil & \\
\hline & Kalbaoush & Beel & 03 & Nil & \\
\hline & Katol & Pond & 03 & Nil & \\
\hline & Silver carp & Pond & 03 & Nil & \\
\hline & Chingri & River & 03 & Nil & \\
\hline & Boal & Beel & 03 & Nil & \\
\hline \multirow[t]{9}{*}{ Soi ani bazar } & Katol & Pond & 03 & Nil & \multirow{9}{*}{$11.11 \%$} \\
\hline & Baeem & River & 03 & Nil & \\
\hline & Chitol & River & 03 & Nil & \\
\hline & Elish & Sea & 03 & Nil & \\
\hline & Telapia & Pond & 03 & Nil & \\
\hline & Boal & Beel & 03 & Nil & \\
\hline & Aaeer & River & 03 & Nil & \\
\hline & Rui & Imported & 03 & Yes (03) & \\
\hline & Silver carp & Pond & 03 & Nil & \\
\hline \multirow[t]{10}{*}{ Park bazar } & Katol & Pond & 03 & Yes (01) & \multirow{10}{*}{$13.33 \%$} \\
\hline & Gras carp & Beel & 03 & Nil & \\
\hline & Rui & Imported & 03 & Yes (03) & \\
\hline & Boal & Beel & 03 & Nil & \\
\hline & Foli & River & 03 & Nil & \\
\hline & Mrigel & Beel & 03 & Nil & \\
\hline & Kalbaus & Beel & 03 & Nil & \\
\hline & Miror carp & Beel & 03 & Nil & \\
\hline & Baeem & River & 03 & Nil & \\
\hline & Aaeer & River & 03 & Nil & \\
\hline \multirow{9}{*}{$\begin{array}{l}\text { Godaon bazar } \\
\text { (Old bus stand) }\end{array}$} & Silver carp & Pond & 03 & Nil & \multirow{9}{*}{$14.81 \%$} \\
\hline & Telapia & Pond & 03 & Nil & \\
\hline & Mrigel & Beel & 03 & Nil & \\
\hline & Miror carp & Pond & 03 & Nil & \\
\hline & Karfu & Pond & 03 & Nil & \\
\hline & Rui & Imported & 03 & Yes (03) & \\
\hline & Bighead & Beel & 03 & Nil & \\
\hline & Katol & Beel & 03 & Yes (01) & \\
\hline & Baeen & River & 03 & Nil & \\
\hline \multirow[t]{14}{*}{ Charabari bazar } & Chitol & River & 03 & Nil & \multirow{14}{*}{$\begin{array}{c}\text { Table } 1 \text { cont next } \\
\text { page }\end{array}$} \\
\hline & Chingri & River & 03 & Nil & \\
\hline & Elish & Sea & 03 & Nil & \\
\hline & Chingri & River & 03 & Nil & \\
\hline & Boal & Beel & 03 & Nil & \\
\hline & Pangas & River & 03 & Nil & \\
\hline & Sorputi & Pond & 03 & Nil & \\
\hline & Telapia & Pond & 03 & Nil & \\
\hline & Silver carp & Pond & 03 & Nil & \\
\hline & Koi & Beel & 03 & Nil & \\
\hline & Rui & River & 03 & Nil & \\
\hline & Taki & Beel & 03 & Nil & \\
\hline & Kalbaus & Beel & 03 & Nil & \\
\hline & Catla & Beel & 03 & Nil & \\
\hline
\end{tabular}


Table 1. Formalin detection in fish in Tangail town. (Contd.)

\begin{tabular}{|l|l|c|c|c|c|}
\hline Name of the bazar & Name of the fish & Source & No. of fish & Formalin presence & Percentage (\%) \\
\hline \multirow{5}{*}{ New bus stand bazar } & Karfu & Pond & 03 & Nil \\
\cline { 2 - 5 } & Telapia & Pond & 03 & Nil \\
\cline { 2 - 5 } & Silver carp & Pond & 03 & Nil \\
\cline { 2 - 5 } & Rui & Imported & 03 & Yes (03) \\
\cline { 2 - 5 } & Mrigel & Beel & 03 & Nil \\
\hline & Elish & Sea & 03 & Nil \\
\cline { 2 - 5 } & Katol & Beel & 03 & Yes (02) \\
\hline & Pangas & River & 03 & Nil \\
\hline & Gras carp & Beel & 03 & Nil \\
\hline & Sorputi & Pond & 03 & Nil \\
\hline & Miror carp & Beel & 03 & Nil \\
\hline & Bighead & Pond & 03 & \\
\hline
\end{tabular}

Table 2. Formalin detection in fish in Tongi town.

\begin{tabular}{|c|c|c|c|c|c|}
\hline Name of the bazar & Name of the fish & Source & No. of fish & Formalin presence & Percentage (\%) \\
\hline \multirow{10}{*}{ Coto bazar } & Boal & Beel & 03 & Nil & \multirow[t]{10}{*}{$0 \%$} \\
\hline & Surma & Sea & 03 & Nil & \\
\hline & Tengra & River & 03 & Nil & \\
\hline & Mrigel & Beel & 03 & Nil & \\
\hline & Telapia & Beel & 03 & Nil & \\
\hline & Katol & Pond & 03 & Nil & \\
\hline & Bighead & Pond & 03 & Nil & \\
\hline & Rui & River & 03 & Nil & \\
\hline & Elish & River & 03 & Nil & \\
\hline & Nilla & River & 03 & Nil & \\
\hline \multirow{10}{*}{$\begin{array}{l}\text { Gazipura bus stand } \\
\text { bazar }\end{array}$} & Foli & Beel & 03 & Nil & \multirow[t]{10}{*}{$20 \%$} \\
\hline & Baeen & River & 03 & Nil & \\
\hline & Chitol & River & 03 & Nil & \\
\hline & Gulsha & Imported & 03 & Yes (03) & \\
\hline & Katol & Pond & 03 & Nil & \\
\hline & Elish & River & 03 & Nil & \\
\hline & Telapia & Pond & 03 & Nil & \\
\hline & Chingri & River & 03 & Nil & \\
\hline & Boal & Beel & 03 & Nil & \\
\hline & Aaeer & Imported & 03 & Yes (03) & \\
\hline \multirow[t]{8}{*}{ Chourasta bazar } & Pooa & River & 03 & $\mathrm{Nil}$ & \multirow[t]{8}{*}{$37.5 \%$} \\
\hline & Pabda & Imported & 03 & Yes (03) & \\
\hline & Rui & Imported & 03 & Yes (03) & \\
\hline & Boal & Beel & 03 & Nil & \\
\hline & Foli & River & 03 & Nil & \\
\hline & Katol & Beel & 03 & Yes (03) & \\
\hline & Rida & Sea & 03 & Nil & \\
\hline & Gras carp & Beel & 03 & Nil & \\
\hline \multirow[t]{6}{*}{ Boro bari bazar } & Butum & Pond & 03 & Nil & \multirow[b]{6}{*}{$\begin{array}{c}\text { Table2 cont next } \\
\text { page }\end{array}$} \\
\hline & Telapia & Pond & 03 & Nil & \\
\hline & Mrigel & Beel & 03 & Nil & \\
\hline & Shing & River & 03 & Nil & \\
\hline & Karfu & Pond & 03 & Nil & \\
\hline & Shol & Beel & 03 & Nil & \\
\hline
\end{tabular}


Table 2. Formalin detection in fish in Tongi town (Table 2 Contd.)

\begin{tabular}{|c|c|c|c|c|c|}
\hline Name of the bazar & Name of the fish & Source & No. of fish & Formalin presence & Percentage (\%) \\
\hline & Silver carp & Pond & 03 & $\mathrm{Nil}$ & \\
\hline & Pangas & Beel & 03 & $\mathrm{Nil}$ & \\
\hline \multirow[t]{11}{*}{ Cherag ali bazar } & Chitol & River & 03 & $\mathrm{Nil}$ & \multirow[t]{11}{*}{$36.36 \%$} \\
\hline & Gulsha & Imported & 03 & Yes (03) & \\
\hline & Elish & Sea & 03 & Nil & \\
\hline & Chingri & River & 03 & $\mathrm{Nil}$ & \\
\hline & Rui & Imported & 03 & Yes (03) & \\
\hline & Pangas & River & 03 & Nil & \\
\hline & Sorputi & Pond & 03 & Nil & \\
\hline & Telapia & Pond & 03 & Nil & \\
\hline & Katol & Imported & 03 & Yes (03) & \\
\hline & Koi & Beel & 03 & Nil & \\
\hline & Aaeer & Imported & 03 & Yes (03) & \\
\hline \multirow[t]{10}{*}{ Tongi bazar } & Foli & Beel & 03 & Nil & \multirow[t]{10}{*}{$20 \%$} \\
\hline & Boal & Imported & 03 & Yes (03) & \\
\hline & Silver carp & Pond & 03 & Nil & \\
\hline & Rui & River & 03 & Yes (03) & \\
\hline & Mrigel & Beel & 03 & $\mathrm{Nil}$ & \\
\hline & Elish & River & 03 & $\mathrm{Nil}$ & \\
\hline & Katol & Beel & 03 & Nil & \\
\hline & Nolla & River & 03 & $\mathrm{Nil}$ & \\
\hline & Pooa & Beel & 03 & Nil & \\
\hline & sorputi & Pond & 03 & Nil & \\
\hline
\end{tabular}

It was found that 16 fishes were formalin contaminated out of 192 fish samples in which $0 \%$ in Santosh bazar, $11.11 \%$ in Soi ani bazar, 13.33\% in Park bazar, 14.81\% in Old bus stand bazar, $0 \%$ in Chara bari bazar and $12.82 \%$ in New bus stand bazar of Tangail town. On the other hand, 33 formalin contaminated fish out of 171 were obtained in which $0 \%$ in Coto bazar, $20 \%$ in Gazipura bus stand bazar, $37.5 \%$ in Chourasta bazar, $0 \%$ in Boro bari bazar, 36.36\% in Cherag Ali bazar and 20\% in Tongi bazar of Tongi town.

Table 3. Percentage of formalin contaminated fish in Tangail and Tongi town.

\begin{tabular}{|c|c|c|}
\hline Name of the town & No. of total sample (N) & Percentage of formalin contaminated fish (n) \\
\hline Tangail & 192 & $8.33 \%(16)$ \\
\hline Tongi & 171 & $19.29 \%(33)$ \\
\hline
\end{tabular}

The study indicates that almost $8.33 \%$ of fish samples in Tangail town and $19.29 \%$ of fish samples in Tongi town were formalin contaminated (Table 3). It has been shown that $75 \%$ Rui fish and $25 \%$ Catla were formalin contaminated in Tangail town (Fig. 2). On the other hand 27.27\% Rui, 18.18\% Gulsha, 18.18\% Aaeer, 18.18\% Hatol, 9.09\% Boal and 9.09\% Pabda were formalin contaminated in Tongi town (Fig. 3). 
Fig. 4 shows that in Tangail town, $75 \%$ imported fishes and $25 \%$ local fishes were formalin contaminated, whereas figure 5 depicts that in Tongi town, $82 \%$ imported fishes and $18 \%$ local fishes were formalin contaminated.

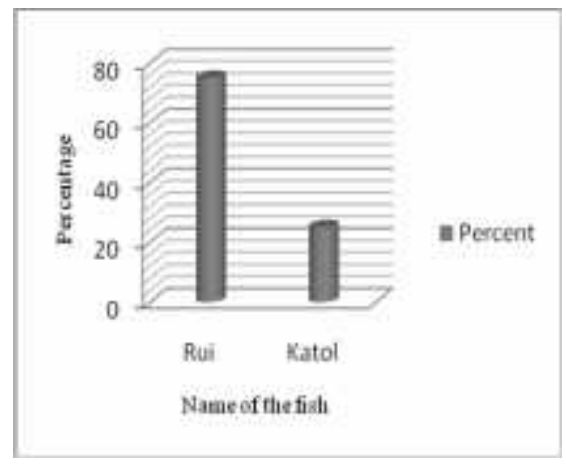

Fig. 2. Percent distribution of various types of formalin contaminated fish in Tangail

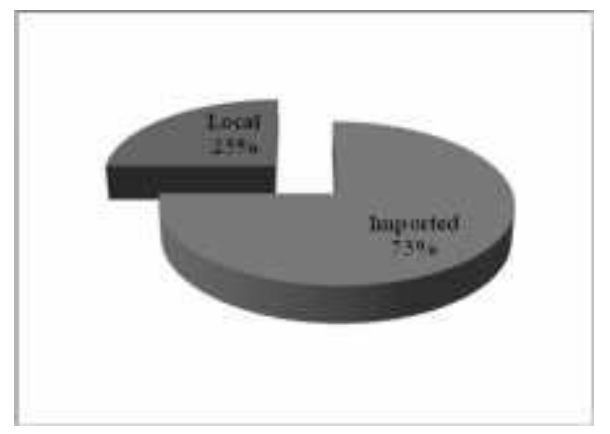

Fig. 4. Percent distribution of local and imported fish (formalin contaminated) in Tangail

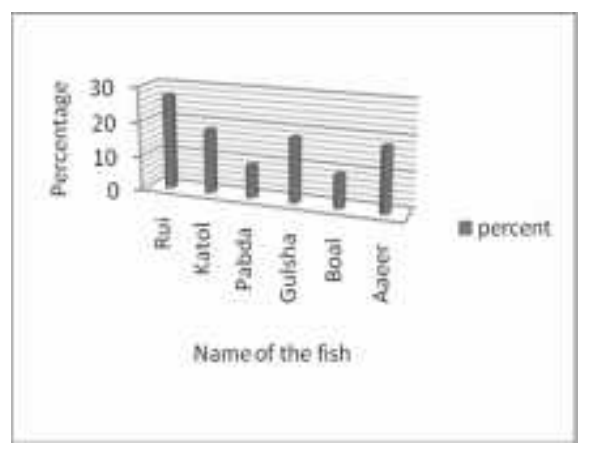

Fig. 3. Percent distribution of various types of formalin contaminated fish in Tongi

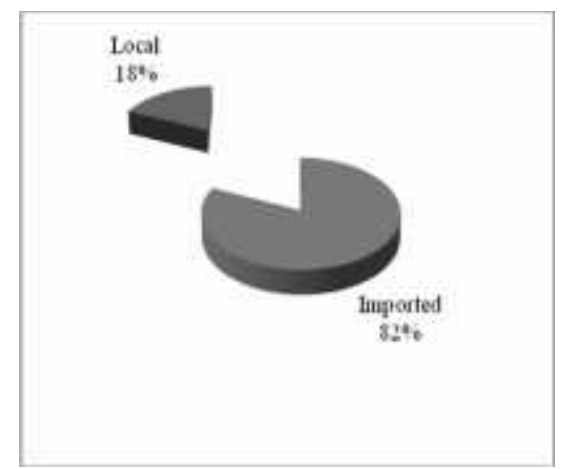

Fig. 5. Percent distribution of local and imported fish (formalin contaminated) in Tongi

It was observed in a study conducted in Dhaka city (Haque and Mohsin 2009) that almost $5 \%$ shops of total consumable fishes contain formalin treated fishes in the fish markets. It was found this intensity varies market to market and species to species. Rui fish was highly affected by formalin, whereas Karwan Bazar represented highest number of formalin treated fish.

\section{Conclusion}

The current study involves a small number of samples to detect formalin in fish in selected local wet market of Tangail and Tongi town. But it gives us a comprehensive picture to understand the extent and magnitude of the scenario. So the government and other agencies can take necessary steps to prevent such type of blacken activities by the fish traders to safe guard public health. 


\section{References}

Ashie INA, Smith JP, Simpson BK, Haard NF (1996). Spoilage and shelf-life extension of fresh fish and shellfish. Critical Reviews in Food Science and Nutrition 36 (1\&2), 87-121. http://dx.doi.org/10.1080/10408399609527720

DoF (Department of Fisheries) (2009). Fish fortnight publication, 2009. Published by the Department of Fisheries, Ministry of Fisheries and Livestock.

FAO (2011). FAO country sector fact sheets placeholder. National Aquaculture Sector Overview: Bangladesh. http://www.fao.org/fishery/countrysector/naso_bangladesh/en [Accessed on May 31, 2011]

Haque E, Mohsin ABM (2009). Intensity of formalin use for consumable fish preservation in Dhaka city. Bangladesh J Fish Int 4(3), 51-53.

Martin H Fischer (2010 October 16). The Toxic Effects of Formaldehyde and Formalin. J Boston Soc Med Sci 5(1), 1822.

MoFL (2011). Ministry of Fisheries \& Livestock, Government of the people's Republic of Bangladesh. http://www.mofl.gov.bd/ [Accessed on May 31, 2011]

National Toxicology Program (2011). Report on Carcinogens, Twelfth Edition. Department of Health and Human Services, Public Health Service, National Toxicology Program. [Accessed on July 05, 2011].

Noordiana N, Fatimah AB, Farhana YCB (2011). Formaldehyde content and quality characteristics of selected fish and seafood from wet markets. International Food Research Journal 18, 125-136.

Sapthahik-2000 (2011). Business men using formalin in fish published in the newspaper Sapthahik-2000. 31 March, 2011.Bangladesh. 